\title{
Reading Nietzsche in Egyptian Context The Concept of Transcendence in
}

\author{
Nietzsche's Thinking(")
}

\section{Prof. Safaa Gaafar (PhD)}

Department of Philosophy

Faculty of Arts - Alexandria University

Alexandria - Egypt

أستاذ الفلسفة الحديثة والمعاصرة

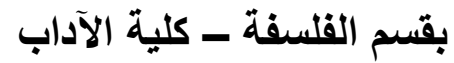

جامعة الإسكندرية

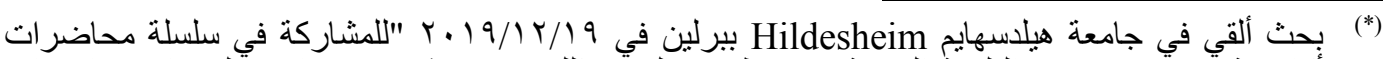

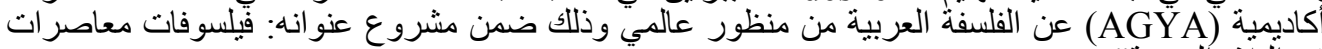




\section{Table of contents}

- Preface

- Pre Egyptian Studies On Nietzsche's Thought

- (1)Salama Moussa (1887 - 1958),

- (2)Abdel Rahman Badawi ( 1917 - 2002)

- (3)Fouad Zakaria (1927-2010)

- (4)Abdel Ghaffar Makkawi ( 1930 - 2012 )

- Reading Nietzsche's Philosophy Of Transcendence

- Transcendence in The Concept of Superman

- Transcendence in the Concept of the Will to Power

- Transcendence in the Concept of Eternal Recurrence of the Same

- Transcendence in the Concept of the Death of old God

- Conclusions 


\section{Preface}

No philosophy in the history of philosophical thought has been misunderstood as Nietzsche's philosophy.

We can maintain that modern philosophy has not yet conceived all that Nietzsche has afforded, and that the metaphysical content of his philosophy is an important task of contemporary philosophy.

Nietzsche was worrying about his time and civilization, and tried to unveil their false masks, and was already able to expose his civilization, and reveal the corruption, decay and nihilism of his age, and we need to make such an attempt in our nihilistic era which is dominated by the concepts of matter and technicity forfeiting its authentic values.

Nietzsche is the "philosopher of disaster" symbolically expressing the coming disaster to be followed by the "rise of the new dawn," and predicted that the crisis of nihilism is just a break" between the death of old-ideals and the birth of new ones.

- Nietzsche knows that in his skillful use of his hammer, he risks destroying all humanity, and that he regains a frightening decision to destroy rather than to be in the middle of the road. He seeks for the return of true self to overcome our own existence and reminds us of those who guide us: the "philosopher" who embodies this deepening consciousness, the "artist" who reveals the new existence and "the saint" who performs the transformation, all are imminent in us by force and closer to us than we imagine.

- Nietzsche is also the proponent of the "Superman" or the "creative man", creativity is a condition of his existence, creativity of the individual, collective self, and the creation of new values after all.

Nietzsche in his book "Human-All-too Human" presents an approximate model of the Superman, saying about the free Spirits that despise to give themselves to worship of the herd as others do, no matter what labyrinths they may face, and when they reach the source of light go through their way lightly often without noise, leaving the sunlight deeply Penetrating. 
Nietzsche defines the Superman in his Will to Power by saying that who determines the values, and guides the will of his age is the superman.

We must consider that future plays an important role for all our evaluations, and we must not look for the laws of our actions behind us, because the superman surpasses the rules, getting free of all restrictions.

Nietzsche wrote in his Will to Power:

"I write to a kind of humanity that has not yet existed, to the masters of the earth... I'm waiting for others on high mountains, they are the healthy men of Joy and happiness."

\section{Pre Egyptian Studies On Nietzsche's Thought (1) Salama Moussa (1887 - 1958)}

A reformer of the Egyptian Renaissance. He is the pioneer of Egyptian socialism. He was born to Coptic parents, and known for his widespread interest in culture and his firm conviction of thought of progress and prosperity.

Salama Moussa belonged to a group of Egyptian intellectuals, including Ahmed Lotfy El-Sayed, who called for simplification of the Arabic language and rules .

The thought of Salama Moussa can be summarized in three directions: first, rationality, modernity and representation in the West, secondly his belief in socialism as a way to achieve social justice, and thirdly, the search for the origins of the Egyptian personality in its pharaonic roots. Added to this is the demand for liberal democracy, secularization and the emancipation of women.

Salama Moussa in his Book "Those Who Taught Me" describes Nietzsche's philosophy as an inspiration, and disclosure .

It is a kind of optimism, and all that is linked with evolution

Mossa wrote an essay in "El Moktatef Magazine" in 1909 titled " Nietzsche and the Son of human being " he maintained that Nietzsche was a philosopher \& linguistic and this explains his charm. 
Nietzsche 's Philosophy could be summarized as follows :

- Its aim is for the sake of the superman not the herd.

- He defended the ethics of masters not slaves trying to find superman to increase intelligibility, health, and power.

- Nietzsche's attack on Christianity is nothing but a call for the great ones to surpass the last man or the herd.

Nietzsche does not afford us with a doctrine or a logic, but a way of thinking to get rid of weakness through cruelty against ourselves, and others.

Mossa maintained that Nietzsche has an obvious human issue, that is to attain human Transcendence, we must fight against weakness, and defend supreme qualifies as being healthy, powerful and intelligible.

- Attractiveness of Nietzsche's philosophy is due to his criticism of traditional morality.

- Mossa believes that Nietzsche may be the most famous European thinker, since he represents the problem of European consciousness and political thought.

- Mossa is asking us to read Nietzsche for his thought is constantly urging us to question and know, he is a great liberating power, who represents human future on this earth.

\section{(2) Abdel Rahman Badawi ( 1917 - 2002)}

One of the most prominent and most productive Arab professors of philosophy in the twentieth century, as his works included more than 150 books distributed between investigation, translation and authorship, and some who are interested in philosophy from the Arabs consider him the first Egyptian existential philosopher, This was so influenced by some European ontologists, led by the German philosopher Martin Heidegger.

After obtaining his doctorate, he was appointed as a teacher in the Department of Philosophy, Faculty of Arts, Fouad University in April 1945, then he became an assistant professor in the same department and college in July 1949. He left Cairo University (Fouad) on September 1950, to establish the Department of Philosophy at the 
Faculty of Arts at Ain Shams University 'Ibrahim Pasha University previously', and in January 1959 he became a professor of chair He worked as a cultural advisor and director of the educational mission in Berne, Switzerland in March 1956 - November 1958.

He left for France in 1967 after the July 23 revolution stripped his family of their possessions. He had worked as a visiting professor at many universities, (1947-1949) in Lebanese universities, (February 1967 - May 1967) at the Institute of Islamic Studies at the College of Arts, Sorbonne, at the University of Paris, (1967-1973) at the Libyan University in Benghazi, Libya, (1973-1974) at the College of "Theology and Islamic Sciences" at the University of Tehran, Tehran and (September 1974-1982) Professor of Contemporary Philosophy, Logic, Ethics and Sufism at the College of Arts, Kuwait University, Kuwait, and finally settled in Paris.

His essential book titled Nietzsche, main topics of this book:

- Nietzsche's extraordinary nature .

- Nietzsche's myth and the real Nietzsche.

- Nietzsche's spiritual crisis.

- His feeling of solitude and its necessity for his thought.

- Philosophy of illness in Nietzsche's thought as a key for health.

- Nietzsche and destroying of old idols.

- The new values in the light of the Will To Power, the Superman, and the Eternal Recurrence of the Same.

Badawi maintains that Amor fati or Love of life increases to the utmost when we believe in the concept of Eternal Recurrence of the Same. Fear of death will be diminished since this significant life will return infinitely.

\section{(3) Fouad Zakaria (1927-2010)}

An Egyptian academic and a scholar of contemporary Arab thought, graduated from the Department of Philosophy, Faculty of Arts, Fouad I University (now Cairo University) in 1949. He was appointed a lecturer at the Faculty of Arts at Ain Shams University, and in 1952 he obtained a master's degree for his thesis 'Naturalism in Nietzsche" from Ain Shams University, and after four years (in 
1956 AD) he obtained a doctorate degree for his thesis "The Problem of Truth" from the same university.

He worked as a professor and head of the Department of Philosophy, Faculty of Arts, Ain Shams University until 1974, after which he moved to Kuwait as Professor and Chairman of the Department of Philosophy at Kuwait University until 1991, in succession of his professor Dr. Zaki Najib Mahmoud. He worked at the United Nations as a consultant for culture and humanities affairs at the National Committee for UNESCO in Cairo, and a consultant for the series "The World of Knowledge" issued by the Kuwaiti "National Council for Culture, Arts and Literature", which is one of its founders. He also headed the editing of the magazines "Contemporary Thought" and "Heritage of Humanity" in Egypt.

He received the State Appreciation Award, the Encouragement State Award in 1962 AD for his book "Espinoza", the Kuwait Foundation for Scientific Progress Award in 1982 AD for his translation of "Wisdom of the West" by Bertrand Russell, the Sultan Al Owais Award in 1991 AD, and the French Association Prize for Education.

Main topics of his book titled Nietzsche:

- Nietzsche as a philosopher, and his idea for revaluation of all values.

- Morality in Nietzsche's thought and his social philosophy.

- Zakaria maintains that Nietzsche is a culture thinker and his task in life is criticizing his culture.

- Zakaria criticizes Nietzsche because of his irrationality and individuality, and they are linked, as he believes, lined together and are signs of romanticism.

- Meanwhile Zakaria maintains that irrationality does a great favor for humanity since it destroys the old habits of mind in its stability and remoteness from this life.

- Zakrakia justifies Nietzsche's attitude maintaining that the circumstances of his age demand this irrationality.

- Finally Zakaria affirms that Nietzsche represents the voice of protesting which is necessary for every progress. 
(4) Abdel Ghaffar Makkawi ( 1930 - 2012 )

- Egyptian philosopher, translator, and writer.

- He is considered as one of the best translators from the German language

to Arabic. He translated works by Kant and Heidegger in addition to many contemporary and critical works.

- Doctorate in modern German philosophy and literature from the University of Freiburg in 1962.

- Worked in the Foreign Indexes Department at the Egyptian Books House.

- Teaching at the German Language Department, 1965.

- Teaching at Department of Philosophy, Faculty of Arts, Cairo University, in 1972.

- Teaching at Sana'a University, Yemen, from 1978 to 1982.

- Teaching at Kuwait University from 1985 to 1995.

- He received the state appreciation award in Egypt.

\section{His main points of view about Nietzsche:}

- Nietzsche represents a beginning and rather an end in the history of modern thought.

- Thinking is the destiny of Nietzsche.

- He is a poet and a philosopher in the profoundest sense.

- His thinking turns poetizing, and the relationship between thought and poetry or between truth and art is a fundamental contradiction which motivate his whole philosophy.

- The main trait of Nietzsche's though is attacking, meanwhile he is linked with what is attacked whether it is metaphysical, platonic, Christian or contemporary.

- Nietzsche's interpretation of life and being is the Will To Power as the most extreme expression of subjective metaphysics as subjective philosophy of the will.

- Nietzsche's philosophy tends to a kind of Transcendence , surpassing the present man, traditional morality and metaphysics . 
- Nietzsche does not speak about something contra Christianity or against European spirit, but he surpasses all attitudes affirming his Transcendence above his present humanity.

- Nietzsche never stop searching this new world, this may be the most important concept of his philosophy .

- The Eternal Recurrence of the Same is the center of Nietzsche's book " Thus Spoke Zarathustra" and it is the center of his other two main ideas:

- The superman and the Will to Power, the Eternal recurrence surpasses the contradiction between past and future that it affords the future with stability of the past and afford the past with the concept of the openness and possibility since it loses its common direction.

- The Eternal Recurrence is Nietzsche's doctrine of the whole world or of the universality of Being.

- This openness into the far world aims at nearness of beings.

- Everyone who experiences the authentic Eternal Recurrence also understands how to get rid of necessity that enslaves him, and how to surpass it to return to it authentically.

\section{Reading Nietzsche's Philosophy of Transcendence by Safaa Gaafar.}

\section{I) Transcendence in The Concept of Superman:}

- The Concept of Transcendence permeates the idea of Superman in Nietzsche's philosophy despite the misinterpretation suffered due primarily to the fact that Nietzsche himself left meanings open, using metaphors and analogies that contributed in one way to mislead his readers, for example, the superman is not a blond monster in the Nazi sense, but is a thinker who resists nihilism in its various forms, and is also a potentiality, and is not evolutionary human in Darwin concept, because the concept of Superman maintains the struggle for Power, not for survival.

The Superman is a call to replace the renewal of life with the homogeneity of morality, the concept of Superman contained the idea of Transcendence in the following meanings: 
1) Self-Transcendence as a Path to Superman.

2) Ethical Transcendence.

3) Metaphysical Transcendence.

4) Ontological Transcendence: openness as a possibility for the future.

\section{1) Self-Transcendence as a Path to Superman:}

The idea of a supreme human being is based primarily on the concept of inequality, opposition and self-overcoming as a possibility triumph over the self, paves the way to the path of uniqueness and creativity, which is the way to the superman, and enables him to take an original position of everything creating new standards .

Nietzsche summaries the qualities of Free Spirit in his book "Human All- too Human" : pure heroism lies in the free spirit, in its way of life and thinking, one of the means by which the superman realized himself is to grant him the right for exceptional acts, such as his experience of self-overcoming, and the exercise of freedom.

\section{2) Ethical Transcendence:}

The Superman embodies the moral ideal of Nietzsche's thinking, who is superior to both good and evil. His main task is to create values, as well as to define the beliefs of the entire age, Nietzsche overcomes the relativity of moral values and goals through the idea of superman, which is the sole purpose of Mankind", superman places a new assessment above the old one, the death of inherited values of good and evil, compassion, and the good becomes the aristocrat and equals the noble with the right and powerful, authentic humanity expresses dialectic between the contempt of present man and the aspiration to the future one.

- Suffering is a necessary condition for creativity, and can be overcome through creativity, and ultimately measured by the way it transcended suffering.

\section{3) Metaphysical Transcendence:}


Human value is determined to be a transitional creature, which is more than it is, and less than it should be, and the highest realization of a human being is what we should look for.

- The last man is a bridge that prepare the way to the Superman, and this will be attained only through the transition and Transcendence from his state to a superior one endlessly.

\section{4) Ontological Transcendence: openness as a possibility for the future:}

There is no final state of man or any existing beings, and this openness characterizes the idea of the Superman. Human being is in a state of becoming and there is no final existence.

The creator or the Superman expresses a vision that penetrates into the living nature of the earthly existence; freedom returns to the earth from the transformation of the existence which aspires to the Superman.

Since human beings are the only creatures that can transcend themselves, Superman is above himself, sacrificing everything for his desire to rise.

The unique creative act is preserving the fundamental and natural differences between human beings.

- We can not separate the concept of Superman from the concept of resistance against his greatest enemies (himself), as he struggles against fundamental nihilism.

His right task is to "create beyond the present man" Thus we can maintain that man is a metaphysical creature whose dialectic over and above self-overcoming is possible for him because of his intrinsic dual nature both animal \& spiritual returns to the earth from the transformation of the existence which aspires to the Superman.

Transcendence in the Concept of the Will to Power:

- The Will to Power is the basis of Nietzsche's metaphysical experience, which is nothing but The will to live in joy and cheerfulness, and life is not but the will of nature. Thus "life 
according to nature means trying to control nature. Nature and life are in constant struggle aiming at the very Transcendence.

- Nietzsche says in The Will to Power:

" To make the world human, it means to be the masters of this world"

it always transcends itself in time, breaks with what it was, and looking for what has not yet come.

- All evaluations in Nietzsche's philosophy are results of the Will to Power; the objective measure of value is The amount of force that increases the value of life .

It's obvious that The Will to Power is the will of selfTranscendence and Overcoming, and the will of Zarathustra' is the will of surpassing the good and evil, and the will to Power becomes the very motive to self-transcendence .

Aspects of Transcendence in the Concept of the Will to Power :

1) Ethical Transcendence.

2) Epistemological Transcendence.

3) Transcendence in Nature.

4) Transcendence in Art.

5) Psychological Transcendence.

6) Metaphysical Transcendence.

\section{1) Ethical Transcendence:}

Life in Nietzsche's Thought is the Will to Power, in the sense that it is the effective element behind all evaluations, and interpretations that we offer to the world. It is the feeling that Power is growing, and that resistance has been eliminated.

\section{2) Epistemological Transcendence:}

Since the will of truth in Nietzsche's thinking is a form of the Will to Power the highest degree of power in knowledge is represented by the power of the supreme power of truth in the processes of the world, which is Becoming . 
-The most important thing that the will of truth does is self affirmation and supremacy .

Transcendental Concepts have permeated Nietzsche's idea of truth, for he implicitly recognizes absolute, and universal principle that governs human experience.

\section{3) Transcendence in Nature:}

Since a living being consists of complex of systems that fight for a sense of power, Nietzsche maintains that vital functions are manifestations of the Will to Power in nature. For example: The law of causality is an expression of a conflict between two unequal elements of power, and the law of change is the Will to Power when another will prevails and surpasses it.

\section{4) Transcendence in Art:}

- Nietzsche maintains that art has more value than truth, for it is the authentic task in life and the metaphysical activity that justifies it.

- The tragic art is a kind of knowledge of the Will to Power, it is altered by the appearance of the ugliness of life and transcends it: The highest will of the artist is the strength above contradictions.

\section{5) Psychological Transcendence:}

The Will to Power is a psychological motivation underlying the entire psychological human Phenomena For example; pleasure is a feeling of strength that expresses the absence of pain, a feeling associated with a secondary phenomenon. Happiness is the feeling that power is rising, and resisting has been overcome.

\section{6) Metaphysical Transcendence:}

The Will to Power, is the will to overcome oneself expressing the tendency of life to ascend creating forms of power infinitely, and its movement is in the process of a vertical movement that continues to rise. It does not cease from self- transcendence, but seeks to transcend, thus expressing the utmost Will to Power. 
The motive of self- transcendence is ultimately Christian, and that Nietzsche's understating of suffering and self-sacrifice as a Christian condition for self- perfection makes him seem more Christian than many other philosophers; Life is to attain selftranscendence, and the spirit does not conflict with life, and its mission is not to destroy life, but to strive for perfection.

\section{(III) Transcendence in the Concept of Eternal Recurrence of the Same:}

- Nietzsche has repeatedly pointed to the difficulty of his idea of Eternity and its importance among his other ideas.

The danger of this idea is that it represents the opposite face of nihilism which claims that nothing is real, and that everything is useless.

- The idea of Eternal Recurrence" means that everything that exists will return infinitely.

There is no beginning, end or even center of the story of the world, because everything that happens in time is repeated with the same identity, including all the good and evil in the world by an infinite number of times.

\section{- Nietzsche says in his "Zarathustra":}

".. I will return with this sun, this earth, and with this eagle and this snake, I will return not to a new life, or a better life, or a similar life; I will return to this particular life in general and in detail. I also preach the noon of the earth and men and the coming of the Superman.."

- It is noted that existence is not a continuous process of infinity, but comes a period Nietzsche calls "the great year of Becoming", and then ends the cycle of the Becoming to begin a new one, and so forth.

The time of existence is divided into cycles, and each cycle is a repetition of the previous ones. 
- As for the "Great Minute of Time, it is that minute that is necessary to recreate all the conditions that created man in cycle of the universe.

- Nietzsche says in his :"Ecce Homo" about Zarathustra:

'I will tell the story of Zarathustra, the basic idea in the book is the idea of the Eternal Recurrence of the Same, this sublime formulation of positivity dating back to August 1881".

It seems that Nietzsche felt that his idea of all the most important ideas, a frightening idea, it appears like a revelation or inspiration.

- We can describe the moment when the idea of Eternal Recurrence came to Nietzsche as the culmination of the philosopher's visions.

- Nietzsche maintains that this idea is a turning point in history, it's the creative free action that Eternity gives to man.

- The Eternal Recurrence of the Same reflects Nietzsche's entire philosophy, seems as the substructure of his philosophy and the deepest of all his ideas.

It seems also like a prophecy or a mystical mystery that our philosopher is trying to reveal.

Nietzsche 's inability to express this idea clearly demonstrates the inability of philosophical heritage he stands on its land.

- It is clear that Nietzsche's criticism of religion, morality and philosophy is a defense of man" by destroying his old perceptions, says Nietzsche: "I want to return all the beauty and majesty we have added to the real or imaginary things to man as his property and product, and this will be the most wonderful defense of man"

- With Nietzsche, we often find two voices, one confirms, the other opposes and modifies, one leads to a pessimistic result, and the other to an optimistic outcome, both are derived from the same premises, but all the hidden destruction is only a necessary prelude to the new construction, "There are colors of 
dawn that have not yet risen", it means that Nietzsche struggle against everything nihilistic in nature, it is followed by a call for positive actions; e.g.) Superman, the Will to Power, amor fati, Eternal Recurrence and the Great Noon, all reflect the idea that Nietzsche tries to provide a solution to his crisis.

- Nihilism in Nietzsche's thinking is a creative nihilism of the powerful, and stands on the opposite side with the nihilism of the weak which is destructive and non creative.

- Nietzsche's nihilism reveals a mysterious form of Transcendence, his attempt to find alternatives to Transcendence expresses clearly his desire for faith, and arising concern that spares no effort in the search for God.

- If divinity is a force in the world, Nietzsche has only expressed that truth, and has only raised the consequences of this fact to a great extent.

- Nietzsche 's heroic break with all things is not based on the will to destroy, rather, on the will to prove, he never imagined the possibility of simply forgetting the historical heritage, since he never lost his preoccupation with the greatness of the past in his entire philosophy even when he refuses to admit it.

\section{1) Mystical Transcendence:}

This concept reveals all beings again, gives life new values and new connotations. In this Recurrence we face the necessity of death and annihilation through surpassing life.

Nietzsche could not overcome metaphysics but in vain, $\mathrm{He}$ is apparently separated from the metaphysical tradition when he moves from the idea of what is within the world to the idea of the world itself.

- Eternal Recurrence is the rise above all things that enter the world to understand the world itself, liberate man and restore the innocence of Becoming, the vision of the light of the world is realized in the sense of excluding all the categories that enter 
morality within the course of time, turning this time into a circle which transcend all beings of the world.

- Nietzsche tried to express the duality inherent in the core of human existence by transforming the process into eternal existence, through a metaphysical translation of the idea of Recurrence, he combined in this idea between two opposing tendencies, namely, the need for finitude and infinitude.

As for the concept of "circle" in the idea of Eternal Recurrence, Nietzsche does not mean it is definitely the engineering circle, but the basic substructure of life to face the Recurrence in its nihilistic form, and therefore the revaluation of all values is necessary, it also requires a new realization of pain as "the basis of pleasure", and if the idea of recurrence in its nihilistic form is the greatest obstacle to life, overcoming this obstacle brings life to a higher level of selfTranscendence. The contradiction between The Will to Power and Eternity will be diminished.

- Eternity is the only metaphysical conception that Nietzsche did not attack or reject, but he has given it new meanings:

- The Superman is now standing in the world's universality to realize the return of the same, opens to the glorious expanse of the world or to a kind of metaphysical height that transcends limited beings.

-We also find in the idea of Recurrence a metaphysical Transcendence that eliminate the difference between freedom and necessity to make the Recurrence the creative free action granted by Eternity to man.

\section{3) Ontological Transcendence:}

The Eternal Recurrence experience is realized for those who experience the feeling of transformation: Man can transforms things and himself through a 'revaluation of all values, and this transformation is immortal .

One of the clearest signs of this transformation is that feeling of joy, cheerfulness, and lightness, as well as that openness into the world and the whole Being. 
- The Ontological Transformation takes place in the meaning of "Lust" which becomes an expression of the cheerfulness of the earth.

- Openness into the world refers to a profound sense of the Ontological transformation of the idea of the Eternal Recurrence.

Nietzsche also uses the symbol of flight and dance to express the existential transformation' that occurs in man when he realizes the idea of Recurrence, and this symbol reflects the deep, and true relationship with the world.

Flight is a symbol of self-effluence in the infinite, and it is a symbol of victory over all finitude of the world.

- The Eternal Recurrence implies a revaluation of all values, what is the driving force necessary to achieve "Self-Transcendence as a condition for the achievement of values as a whole.

- It also achieves a kind of Transcendence in the form of creativity which opens its path to the creator, who becomes free to determine his own destiny, and expresses the "amor fati", the highest point of compatibility between freedom and necessity.

The idea of the Eternal Recurrence expresses the highest form of positivity, but it focuses on the Individual existence and his creativity at the moment

- "Love of Eternity" and orientation towards the world express the Ontological Transcendence, that does not go beyond the world, to the surpassing Eternity, but to the Eternity of "this world", and it is all about the Eternal Moment that activates human struggle to the utmost. :

"Amor fati" expresses the supreme meanings of selfTranscendence and overcoming". Here it turns into the will of annihilation that needs the greatest possible strength, and is an expression of this formula of human greatness that emphasizes the feelings of strength and joy at every moment.

\section{4) Religious Transcendence:}


- The idea of Eternal Recurrence expresses Nietzsche's expectation of a new concept of salvation, that he developed the theory of Recurrence to replace. metaphysics and religion in the traditional sense.

In the idea of Eternal Recurrence God expresses the highest power, it is God beyond the limits of good and evil, and He is present in every moment.

It seems that Nietzsche's subtle references to the concept of God under the name of the world, which constantly creates new forms, show a longing for the idea of God, and encompass the whole philosophy of the universe.

- Nietzsche develops a new concept of "Eternity" That glorifies this earth and this world as the real homeland of man, and makes the body the true soul of him, and thus glorifies man's tendency to rise above himself and his existential state.

- Religion is the religion of Free Spirits, the most emancipated, and high-spirited souls. In fact, the function of the Eternal Recurrence is defined as an ethical existential experience based on an eschatological Christian premise, despite Nietzsche's insistence on his denial.

The Conception of salvation in the new religion is achieved by the new relationship discovered by Nietzsche between "Eternity, the Same, and Moment". Eternity is the ring of rings, and the ring is an absolute rejection of the idea of automatic or teleological time, and his entire existence is the Eternal Recurrence of the Same.

We can always resolve our issues, always and again as we resolve it at this Moment, because every Moment we live has a connotation above our individual lives, and because the Moment of the decision we take in this earth decides on all the recurring events of earthly existence, just as our earthly life in the view of the heavenly religious determines the destiny of the soul in the other world.

If something is achieved in the world "at every moment", and if man lives this thing as his own existence, he asserts victory over all 
existence "at every Moment", and this excludes any kind of teleology from the concept of the Moment, because you must live the present Moment completely, it can not be neglected to or postponed for memories of the past. Either man lives in the present or does not live at all.

\section{IV) Transcendence in the Concept of the Death of old God:}

Death of old God departs from any religious significance and only means the death of every ideal that takes the form of another world created for man.

This death expresses only the transformation of man and the earth .

Time and space gain the greatest possible existential significance, immortality is attained in this life, and every Moment becomes Eternity in which man creates present and future values.

This implies a kind of inverted" Transcendence" that attains Eternity in this world, replacing the earth with the other world after giving it all the transcendent qualities of the other world.

The Death of old God maintains the heroic character of human existence, where man possibilities become open freely.

It also means liberation from the spirit of gravity, and transcendence above traditional metaphysical heritage, it is a call to a new innocence in life.

The Death of old God finally means nihilism, paving the way for a new dawn and a revaluation of all values.

Nietzsche 's nihilism reveals a mysterious form of Transcendence, and his attempt to find alternatives to expresses his desire for faith and his thinking allows for a revival of God.

Nietzsche's philosophy is all linked to the problem of God, who is the main character in his thought.

Nietzsche is against condemnation of the value of life, which is the most Important value and does not attack religion, but he fights 
against traditional evaluation and metaphysics, anticipating a new era, in which the superman transcends himself, and surpasses metaphysical heritage through a new concept of religion, aiming at a new concept of salvation. 


\section{Conclusions}

\section{I) Aspects of Transcendence in the Concept of Superman:}

1) Self - Transcendence:

Surpassing the self is a path leading to the superman, since it paves the way to creativity, which leads to Superman, this overcoming, is nothing but a dialectical relationship by means of which this concept is realized.

\section{2) Moral Transcendence:}

According to this aspect, man embodies Nietzsche's moral ideal and surpasses both of good and evil, and becomes the creator of all values. If the traditional morality is hostile to life, then rejecting it is the way to attain the utmost and greatest power of humanity.

- Nietzsche's morality is only to find another new meaning of morality that surpasses the old one, thus surpassing compassion and the feeling of guilt and sin expresses the highest positive formula in this life.

\section{3) Metaphysical Transcendence:}

It means Transcendence of the present man as a transitional stage , and a bridge preparing the way to the Superman, and achieves that Transcendence by moving endlessly from its current state to a higher one.

\section{II) Aspects of Transcendence in the Concept of Will to Power}

\section{1) Ethical Transcendence:}

The Will to Power becomes the effective influence behind all evaluations and interpretations we offer to the world.

Good, for example, becomes all that surpasses man's sense of power and Will to Power. The three values, truth, goodness and beauty become tools used by life to rise and grow. 


\section{2) Metaphysical Transcendence:}

In this kind of transcendence, The Will to Power is the will to overcome the self, which in turn expresses the tendency of life to ascend, creating forms of power infinitely, and expressing the utmost Will to Power.

\section{III) Aspects of Transcendence in the Idea of Eternal Recurrence of the Same:}

\section{1) Metaphysical Transcendence:}

This idea Transcends all things within this world, surpassing all metaphysical and moral interpretations of existence, turning time into a ring in which everything dances a circular dance.

"Eternity" is the only metaphysical concept that Nietzsche did not attack, but gave it new meanings, and the soul is in totality of time and enjoy presence everywhere. This idea eliminates the difference between freedom and necessity.

\section{2) Ontological Transcendence:}

It means the transformation of the existential state of man where the presence and the necessity of the past turn into lightness of laughter that surpass man.

- Thanks to the Eternal Recurrence, a person's understanding of existence is transformed, everything is understood in the light of the surrounding world.

An ontological transformation also occurs when a person feels "love of Eternity" as a result of his caring attitude towards this world.

It is all about the Eternal Moment that arouses the struggle of man to the greatest extent of nobility and tragedy.

-The word God does not mean religious power at all, but as a symbol, it refers to the relationship between ontological idea and the moral ideal. Nietzsche's struggle is directed against traditional moral ontology . 
- His aim seems to be to overturn the traditional ontology, calling for a new innocence in life, and for a revaluation of all values.

- It is quite evident that Transcendence is present in the philosophy of Nietzsche; words like above, beyond, and after are frequently repeated in Nietzsche's writings, especially in "Thus spoke Zarathustra", These words are the most indicative of his thinking and philosophizing, moreover Nietzsche repeats the word "sublimation in his writings, which means trying to overcome oneself, and surpass it endlessly signifying THE CORE OF HIS PHILOSOPHY .

\section{Thus, the rereading of the concept of "the Death of Old God" may refer to four meanings:}

1) The end of every ideal takes the form of another world behind man.

2) Preservation of the heroic character of human existence.

3) Freeing oneself from the traditional metaphysical heritage.

4) The advent of nihilism which means the absence of values and meanings of the existence.

Are we in need of Nietzsche once again? 


\section{Refernces:}

1- Jaspers, Karl, "Nietzsche: An Introduction to the Understanding of His Philosophical Activity", trans. by C. F. Wallraff, F. J. Schmitz, Regnery/ Gateway, Incorporated, USA, 1979.

2- Nietzsche, F., "Also Sprach Zarathustra: Werke in drei Banden", Herausgeg., Von Karl Schlechta, Carl- HauserVerlag, Munchen, 1955.

$3-$ , "Ecce Homo, Nietzsche Werke in drei Baenden", herausgeg Von Karl Schlechta, Carl HausterVerlag, Munchen, 1955.

4, Human All- too- Human, A Book for Free Spirits", trans. by Marion Faber, Lehmann, Stephen, The Uni. of Nebraska Press, USA, 1984.

$5-$ , "The Will to Power", trans by W. kaufmann and R. J. Hollingdale, Random House, Inc., Vintage Books ed., New York, 1968.

6-

"Thus Spoke Zarathustra", trans. by R. J. Hollingdale, Penguin Books, Great Britain, 1969. 
